\title{
Comparing physicochemical properties and antioxidant potential of sumac from Iran and turkey
}

\begin{abstract}
Sumac is a medicinal plant that used as a spice. The sour red small epicarps of the fruit are applied in traditional medicine and cookery. In this study, some physical, chemical and antioxidant properties of its aqueous and ethanolic extracts of the sumac fruits of Iran were investigated. The average $\mathrm{m} 1000$, bulk density and porosity percentage ranged from $15.9-16.9 \mathrm{~g}, 304.6-306.7 \mathrm{~kg} / \mathrm{m} 3$ and $68.31-97.26 \%$, respectively. The galvanized sheet with the lowest static friction coefficient was the best surface for the fruit transfer. The mean length, width, thickness and volume were in the range of 4.73 $4.98 \mathrm{~mm}, 4.08-4.54 \mathrm{~mm}, 2.33-2.51 \mathrm{~mm}$ and $17.64-22.46 \mathrm{~mm} 3$, respectively and the mean sphericity coefficient varied from 0.73 to 0.76 . This information is of great importance for the design of the equipment of harvest, transfer and processing of sumac fruit. This study also represent that the antioxidant activity, free radical scavenging and reducing capacity of the ethanolic extract were higher than those of the aqueous one. Moreover, the ethanolic extract had a larger total phenol and anthocyanin content as compared to the aqueous one.
\end{abstract}

Volume 5 Issue 2 - 2017

\author{
Mazaheri Tehrani M,' Hesarinejad MA,' Seyed \\ MA Razavi,' Mohammadian R, ${ }^{2}$ Poorkian $\mathrm{S}^{2}$ \\ 'Department of Food Science and Technology, Ferdowsi \\ University of Mashhad, Iran \\ ${ }^{2}$ Samin Dasht Company, Mashhad, Iran
}

\begin{abstract}
Correspondence: Hesarinejad MA, Department of Food Science and Technology, Ferdowsi University of Mashhad, PO Box: 91775-II 63 Mashhad, Iran,

Email ma.hesarinejad@gmail.com
\end{abstract}

Received: December 15, 2016 | Published: November 24, 2017

Keywords: antioxidant, chemical, physical properties, sumac, DPPH

\section{Introduction}

Spices and aromatic plants are utilized in the food industry, firstly because of the transfer of desirable flavor and aroma and secondly due to having antimicrobial activity which increases the shelf-life of foodstuffs. ${ }^{1}$

The Genus Rhus is comprised of more than 250species and are characterized well using phenolics and triterpenes. Rhusglabra L. was traditionally used by Indians, native to North America, to treat bacterial diseases such as Syphilis, Gonorrhea and diarrhea. ${ }^{2}$ Rhuscoriaria $L$. , known as sumac, is another member of this genus which grows naturally in a vast district, from the Canary Islands (located in the Atlantic Ocean to the Mediterranean coasts, Iran and Afghanistan. ${ }^{3,4}$

Sumac (Rhuscoriaria L), a member of the Anacardiaceae family, is a small shrub with a height of $1-5 \mathrm{~m}$ and leaves comprised of 9-15 leaflets which are jagged and covered with wool. It grows in warm and mild-weather regions..$^{5}$ The leaves color tends to be red in fall and it is one of the specifications of the plant. ${ }^{6}$ Sumac has been used as a spice or medicinal plant during hundreds of years. ${ }^{4}$ The applied part in traditional medicine and Iranian cookery are the sour red small epicarps of the fruit. ${ }^{7}$

Sumac is employed in the Iranian traditional medicine as an astringent, stancher and ant diarrheal agent. It is also used to eye trachoma, and to prevent the incidence of pox in eye. ${ }^{3,8-11}$ The sumac spice is obtained from chopping the fruit of this plant and is used as a seasoning for kebab and various salads due to its sour flavor $(\mathrm{pH}=2.5)$ which is caused by the presence of citric acid and malic acid.

Clinical, food-protective, antimicrobial and physicochemical properties of the sumac extract have been investigated in different researches. ${ }^{12-22}$ Large amounts of tannins have been observed in the aqueous extract of the dried leaves of sumac $(R$. coriaria $L.){ }^{23}$ Recently, the superoxide radical scavenging activity. ${ }^{24}$ and the mineral content of sumac leaf and fruit have been examined. ${ }^{25}$ Recovery of the phenolic compounds from different solvents is influenced by the solvent polarity and the solubility of these compounds in the solvent. ${ }^{26}$ The polarity range of polyphenols is widespread and consequently, a large number of solvents can be taken into account. Therefore, selection of a proper solvent for the extraction of the phenolic compounds from all samples is difficult. ${ }^{26}$

Different solvents and numerous extraction techniques can be applied in order to extract antioxidant compounds from plant tissues. The polarity degree of various solvents affects the extraction extent of polyphenolic compounds. The solubility of polyphenolic compounds differs, depending on the type of solvent, degree of polymerization and their interaction with other compounds present in plant tissues. Numerous studies have been carried out on the engineering properties of many seeds, including fenugreek, lentil, guan, cotton, coriander, flaxseed, pomegranate, cress, balangu, basil, plantain, sage, millet, cannabis, grain, sesame, quinoa and sumac. ${ }^{25,27-40}$

Engineering properties have a special importance in postharvest processes. ${ }^{41}$ For instance, the seed dimensions and shape influence the selection of the suitable sieve mesh. Angle of repose and frictional properties are used in the design of silos, storage tanks and conveyors. Although literature review shows that many researchers have been conducted on the physical properties of food and agricultural products and even on the sumac of other countries, no research has been performed up to now on the engineering properties of the Iranian sumac. Shape and size, bulk density, particle density, porosity, weight, static and dynamic friction coefficients are of the most important physical properties which are functions of moisture. The physical properties of agricultural products are needed for the design and manufacture of the equipment of transfer, processing, sorting, grading and qualitative assessment of such products. ${ }^{42}$ In another research carried out by Özgüven $\mathrm{F}$ et al ${ }^{43}$ on the physical, mechanical and aerodynamic properties of pine nut, some properties, including the cracking force, frictional properties such as the static friction coefficient and the dynamic angle of repose of the seed, core 
and crust were measured. These properties are useful for designing the equipment of processing, storage, hopper and handling. ${ }^{43}$

The aim of this study was to determine and investigate the physical properties, including the dimensions, m1000, particle density, bulk density, porosity and static friction coefficient, in addition to the chemical properties such as the chemical composition of the sumac fruits of Iran. We also aimed to measure the total phenol content, total anthocyanin content, reducing power and the DPPH free radical scavenging power of the aqueous and ethanolic extract of sumac Epicarp and seed and compare it with the sumac of Turkey and Syria.

\section{Materials and methods}

\section{Materials}

Sumac clusters were supplied from the gardens of Gonabad, Ferdows and Zoshk (Khorasan, Iran) and cleaned up manually and separated from other plant residues. The physical tests of the sumac seeds were performed at the moisture content of $5.0 \pm 0.2 \%$. For the chemical tests, the fruits were ground into a coarse-particle powder using a pestle and mortar and separated from the seeds using a sieve. The epicarp and seeds were milled and passed through a 60 mesh screen. The separation performance of the epicarp and whole seed was calculated using the following equation:

$$
\text { separationefficiency }(\%)=\frac{\mathrm{A}}{\mathrm{B}} \times 100
$$

Where A represents the Epicarp and the whole seed, and B denotes the whole seed and the sumac clusters.

\section{Physical properties}

Dimensions: In order to determine the length, width and thickness of the sumac fruits, 50 seeds were selected randomly and their dimensions were measured with a caliper.

$\mathbf{m}_{1000}$ and particle density: $\mathrm{In}$ order to determine $\mathrm{m}_{1000}, 100$ seeds were chosen randomly and weighed using a digital balance. $\mathrm{m}_{1000}$ was obtained through multiplying the measured mass by 10 . The true density was measured through the pycnometer method using toluene. In this method, the true density $\left(\rho_{t}\right)$ was calculated using equation (2). ${ }^{32}$

$$
\tilde{n}_{t}=\frac{m}{V_{t}}
$$

Where $\mathrm{m}$ is the mass of the poured seeds $(\mathrm{kg})$ and $\mathrm{V}_{\mathrm{t}}$ stands for the volume of the displaced liquid $\left(\mathrm{m}^{3}\right)$.

Bulk density and porosity: In order to determine the bulk density $\left(\rho_{\mathrm{b}}\right)$, the seeds were poured from a height of $15 \mathrm{~cm}$ with a constant rate into a container with a certain volume. Then, the container was weighed and the bulk density was computed by equation (3): ${ }^{32}$

$$
\tilde{\mathrm{n}}_{\mathrm{b}}=\frac{\mathrm{m}}{\mathrm{V}}
$$

Where $\mathrm{m}$ is the seed weight $(\mathrm{kg})$ and $\mathrm{V}_{\mathrm{b}}$ denotes the container volume $\left(\mathrm{m}^{3}\right)$.

The porosity percentage $(\varepsilon, \%)$ was calculated through the Mohsenin equation (equation 4): ${ }^{32}$

$$
\varepsilon=\left[\left(\rho_{t}-\rho_{b}\right) / \rho_{t}\right] \times 100
$$

Static friction coefficient: A ramp with an adjustable slope was applied to determine the static friction coefficient. A fiberglass box with the dimensions of $4 * 10^{*} 15 \mathrm{~cm}^{3}$ was placed on the frictional surface and filled with the seeds. The applied surfaces were made of multi-layered rubber, plywood and galvanized iron sheet. First, the box was lifted a little from the respective surface to prevent any contact between the box and the surface. The frictional surface is a part of the apparatus which has a joint at one end so that the non-hinge end could be lifted gently using a bolts and nuts system and consequently, the slide angle $(\alpha)$ was considered as the friction angle. Finally, the static friction coefficient was calculated using equation (5): ${ }^{32}$

$$
\grave{i ̀ ~}_{\mathrm{s}}=\text { taná }
$$

\section{Chemical properties}

The chemical composition (moisture, ash and fat) of sumac was determined according to AOAC (A.O.A.C., 1990). The protein content was measured through the Kjeldal method. ${ }^{44}$

Extract preparation: The aqueous and ethanolic extracts of epicarp and seed were prepared using distilled water and ethanol 96\% through percolation. The extraction procedure was as follows:

The ethanolic extract was obtained after $24 \mathrm{~h}$ of immersing $10 \mathrm{~g}$ of the epicarp powder or the sumac seed in $100 \mathrm{ml}$ of ethanol $95 \%$ at ambient temperature..$^{45}$ The aqueous extract was acquired after $1 \mathrm{~h}$ of immersing $10 \mathrm{~g}$ of the epicarp powder or the sumac seed in $100 \mathrm{ml}$ of distilled water at ambient temperature. ${ }^{46}$ The obtained extracts were separated from the solid matter by centrifugation and concentrated using a rotary evaporator and dried at $40^{\circ} \mathrm{C}$ with a drier. The dry powders resulted from the samples were stored at $-18^{\circ} \mathrm{C}$ until use.

The measurement of the total phenol content, total anthocyanin content, reducing power and free radical scavenging were carried out on the extracts mixture.

The extraction efficiency $(\mathrm{w} / \mathrm{w})$ was calculated using the following equation:

$$
\text { Efficiency }(\%)=\frac{A}{B} \times 100
$$

where A represents the weight of the aqueous or the ethanolic extract and B stands for the weight of the epicarp or seed.

Determination of the total phenol content of the extracts: The total phenol content of the extracts was measured through the FolinCiocalteu micro-method. ${ }^{47} 20 \mu 1$ of the reaction solution was mixed with $1.16 \mathrm{ml}$ of distilled water and $100 \mu \mathrm{l}$ of Folin- Ciocalteu reagent. After 1-8min, $300 \mu \mathrm{l}$ of $\mathrm{Na}_{2} \mathrm{CO}_{3}$ solution $(20 \%)$ was added to the above solution. The obtained mixture was kept at $40^{\circ} \mathrm{C}$ for $30 \mathrm{~min}$ 
and the absorbance values of the samples were measured at $760 \mathrm{~nm}$. The total phenol content of the extracts was expressed as Gallic acid equivalent considering the equation of the standard curve.

Determination of the total anthocyanin content of the extracts: The anthocyanin absorbance values of the extracts were measured at 510 and $700 \mathrm{~nm}$ at $\mathrm{pH}=1$ and $\mathrm{pH}=4.5$ using a UV-120-02 spectrophotometer (Shimadzu, Japan) and the anthocyanin concentration of the extracts was calculated as mg cyaniding-3-glycoside $/ \mathrm{kg}$ dried extract via the differential $\mathrm{pH}$ method. ${ }^{48}$

$$
\mathrm{A}=\left(\mathrm{A}_{510}-\mathrm{A}_{700}\right)_{\mathrm{pH} 1.0}-\left(\mathrm{A}_{510}-\mathrm{A}_{700}\right)_{\mathrm{pH} 4.5}
$$

DPPH free radical scavenging assay: The free radical scavenging ability of the extracts was performed based on Hatano et al. ${ }^{49}$ Various concentrations $(10-50 \mu \mathrm{g} / \mathrm{ml})$ of the extracts were prepared. $0.3 \mathrm{ml}$ of each mixture was added to $2.7 \mathrm{ml}$ of the methanolic solution containing DPPH $(0.02 \mathrm{~g} / \mathrm{l})$. The samples were kept in darkness at ambient temperature for $30 \mathrm{~min}$. the absorbance values of the samples were measured at $517 \mathrm{~nm}$ and the radical scavenging percentage was calculated using the following equation:

Freeradicalscavenging $(\%)=(($ absorbancevalueofthesample - absortancevalueoftheblanksample $) /$ absorbancevalueoftheblanksample $) * 100$

Reducing power: This test was conducted to examine the power of the extracts in reducing Fe (III). ${ }^{47} 1 \mathrm{ml}$ of the sample solution $(10-50 \mu \mathrm{g} /$ $\mathrm{ml})$ was mixed with $2.5 \mathrm{ml}$ of the phosphate buffer $(0.2 \mathrm{M}, \mathrm{pH}=6.6)$ and $2.5 \mathrm{ml}$ of potassium ferricyanide $\left(\mathrm{K}_{3} \mathrm{Fe}(\mathrm{CN})_{6}, 10 \mathrm{gl}^{-1}\right)$ and heated at $50^{\circ} \mathrm{C}$ for $30 \mathrm{~min}$. after that, $2.5 \mathrm{ml}$ of trichloroacetic acid $\left(100 \mathrm{gl}^{-1}\right)$ was added and the mixture was centrifuged for $10 \mathrm{~min}$. Eventually, $2.5 \mathrm{ml}$ of the supernatant was blended $2.5 \mathrm{ml}$ of distilled water and $0.5 \mathrm{ml}$ of $\mathrm{FeCl}_{3}\left(1 \mathrm{gl}^{-1}\right)$ and the absorbance values of the samples were read at $700 \mathrm{~nm}$. The $\mathrm{IC}_{50}$ extract concentration was obtained from the curve of the absorbance values at $700 \mathrm{~nm}$ against the extracts concentration. BHT (a synthetic antioxidant) was used as the blank sample.

\section{Results and discussion}

\section{The physical properties of the sumac seed}

The physical properties of the sumac fruits harvested from Iran are shown in Table 1 . In most cases, the reported values were nearly similar to each other and to those reported for the Turkish sumac fruit.

The $\mathrm{m}_{1000}$ of this sumac ranged from 15.9 to $16.9 \mathrm{mg}$. This range was less than that obtained for the Turkish sumac. The bulk density and porosity were in the range of $304.6-306.7 \mathrm{~kg} / \mathrm{m}^{3}$ and $68.31-$ $97.26 \%$. The average bulk density and porosity were more than those reported for the Turkish sumac.

The range of the static friction coefficient was determined as $0.67-$ 0.69 for rubber, $0.60-0.63$ for plywood and $0.48-0.51$ for galvanized iron sheet. The mean static friction coefficient of rubber and plywood was higher and these two surfaces are inappropriate for transfer. The lowest coefficient pertained to the galvanized iron sheet. The friction coefficient of agricultural products generally depend on the properties of the foodstuff, moisture content, surface properties, slide speed and the surface material on which the food product moves. ${ }^{50}$ Under the same conditions, the surface properties of the seed are the major factor in terms of the slide speed, surface material and the moisture content.
These properties cause the difference between the friction coefficients of various seeds.

\section{Chemical properties of the sumac seed}

The approximate contents of the chemical components of sumac fruits are summarized in Table 2. The results indicated that the different compounds of different ecotypes of sumac (Rhus coriaria) were similar. However, these results were a little different from those of Özcan M et al. ${ }^{25}$ for the Turkish sumac and Kossah et al. ${ }^{51}$ for the Syrian one. The $\mathrm{pH}$ of the Syrian sumac has been reported to be equal to $3.7^{50}$ while the $\mathrm{pH}$ of this sumac varied from 2.68 to 2.76 .

Determination of the total phenol content, total anthocyanin content and extraction efficiency: Tables 3 present the values of the extraction efficiency as well as the total anthocyanin content and total phenol content of the aqueous and ethanolic extracts of different ecotypes of the Khorasan sumac. The results revealed that the solvent type affected the extraction efficiency and the total phenol content of each of the extracts. The total phenol content extracted from sumac with ethanol $96 \%$ and water were 10.17 and 4.78 (g Gallic acid $/ \mathrm{kg}$ dried extract), respectively. The ethanolic extract had the highest extraction efficiency and total phenol content. It seems that the extraction efficiency of the phenolic compounds decreased with the rise in the solvent polarity. In general, the hydrophilic and hydrophobic properties of phytochemical compounds have a considerable effect on their solubility in the applied solvent. Hence, the solvent polarity could have an important role in the extraction efficiency of these compounds. $^{52}$

By creating a completely polar medium, water dissolves a low amount of low-polar phenolic compounds. Furthermore, the aqueous extract contains large amounts of impurities such as organic acids, proteins and soluble sugars, which can interfere in distinguishing and measuring the total phenol content..$^{53}$

Moreover, numerous factors influence the total phenol content of plant tissues, including the genetic factors, extent of sunlight, soil conditions, degree of maturing upon harvest, environmental conditions, climate, post-harvest processing and storage conditions $\mathrm{s}^{54}$ ).

As shown in Table 3, the total anthocyanin content of the ethanolic and aqueous extract was equal to 198.12 and $128.19 \mathrm{mg} / \mathrm{kg}$ extract, demonstrating the total anthocyanin content of the ethanolic extract was higher than that of the aqueous one.

Many studies have reported the direct correlation between the total phenol content and antioxidant activity; nevertheless, Mata AT et al., ${ }^{55}$ found out that the antioxidant activity of plant extracts is not correlated with their high content of phenolic compounds. The solubility of a large number of compounds may be high in a solvent; nonetheless, some of them have a low antioxidant activity or are inactive in this respect. ${ }^{56}$

It has been observed in the studies of former researchers that all parts of sumac, including its fruit, contain noticeable amounts of tannins (glutannin). In a study which has taken a general look at the components present in sumac fruit, the anthocyanins and lipids has been distinguished as the principle components of sumac fruit. ${ }^{57}$ Myrtillin, Delphidin and Chrysanthemin have been distinguished as the main anthocyanins of sumac fruit. ${ }^{58}$ 
Table 1 Biophysical properties of the Iran sumac

\begin{tabular}{|c|c|c|c|c|c|c|c|c|c|c|c|c|c|}
\hline \multirow[b]{2}{*}{ Region } & \multirow{2}{*}{$\begin{array}{l}\text { Length } \\
(\mathrm{mm})\end{array}$} & \multirow{2}{*}{$\begin{array}{l}\text { Width } \\
(\mathrm{mm})\end{array}$} & \multirow{2}{*}{$\begin{array}{l}\text { Thickness } \\
(\mathrm{mm})\end{array}$} & \multirow{2}{*}{$\begin{array}{l}\text { Geometric } \\
\text { mean } \\
\text { diameter } \\
(\mathrm{mm})\end{array}$} & \multirow{2}{*}{$\begin{array}{l}\text { Weight } \\
\text { of } \mathbf{m}_{1000} \\
\text { (g) }\end{array}$} & \multirow{2}{*}{$\begin{array}{l}\text { Volume } \\
\left(\mathrm{mm}^{3}\right)\end{array}$} & \multirow{2}{*}{$\begin{array}{l}\text { Sphericity } \\
(-)\end{array}$} & \multirow{2}{*}{$\begin{array}{l}\text { Bulk } \\
\text { density } \\
(\mathrm{kg} / \\
\left.\mathrm{m}^{3}\right)\end{array}$} & \multirow{2}{*}{$\begin{array}{l}\text { Porosity } \\
(\%)\end{array}$} & \multicolumn{3}{|c|}{ Coefficient of static friction } & \multirow[b]{2}{*}{ Reference } \\
\hline & & & & & & & & & & Rubber & Plywood & $\begin{array}{l}\text { Galvanized } \\
\text { iron sheet }\end{array}$ & \\
\hline Gonabad* & 4.98 & 4.54 & 2.51 & 3.84 & 16.3 & 22.46 & 0.76 & 306.7 & 68.31 & 0.68 & 0.61 & 0.49 & This study \\
\hline Ferdows* & 4.83 & 4.08 & 2.33 & 3.58 & 16.9 & 17.64 & 0.73 & 304.6 & 97.26 & 0.69 & 0.63 & 0.51 & This study \\
\hline Zoshk* & 4.73 & 4.21 & 2.36 & 3.6 & 15.9 & 18.44 & 0.75 & 305.4 & 91.16 & 0.67 & 0.6 & 0.48 & This study \\
\hline Turkey & 4.72 & 3.9 & 2.64 & 3.64 & 18 & 19.49 & 0.77 & 304.25 & 68.52 & 0.675 & 0.607 & 0.482 & $\begin{array}{l}\text { Özcan M et } \\
\text { al. }{ }^{25}\end{array}$ \\
\hline
\end{tabular}

*Gonabad, Ferdows and Zoshk are regions of Iran.

Table 2 The compounds of sumac

\begin{tabular}{|c|c|c|c|c|c|c|}
\hline Reference & pH & Ash (\%) & Protein (\%) & Fat $(\%)$ & Moisture (\%) & Regions \\
\hline This study & 2.68 & $2.0 \pm 0.2$ & $2.6 \pm 0.1$ & $7.1 \pm 0.3$ & $9.6 \pm 0.4$ & Gonabad* \\
\hline This study & 2.76 & $1.8 \pm 0.2$ & $2.4 \pm 0.1$ & $7.2 \pm 0.4$ & $10.2 \pm 0.5$ & Ferdows* \\
\hline This study & 2.71 & $1.8 \pm 0.2$ & $2.3 \pm 0.1$ & $7.0 \pm 0.4$ & $9.9 \pm 0.5$ & Zoshk* \\
\hline Kossah et al. ${ }^{51}$ & - & $2.66 \pm 0.33$ & $2.47 \pm 0.12$ & $7.51 \pm 0.44$ & $11.8 \pm 0.53$ & Syrian \\
\hline Kossah et al. ${ }^{51}$ & - & $6.64 \pm 0.03$ & $11.56 \pm 0.66$ & $4.31 \pm 0.27$ & $5.37 \pm 0.14$ & Turkey \\
\hline Özcan M et al. ${ }^{25}$ & 3.7 & $1.8 \pm 0.4$ & $2.6 \pm 0.2$ & $7.4 \pm 1.6$ & $10.6 \pm 1.1$ & Turkey \\
\hline
\end{tabular}

*Gonabad, Ferdows and Zoshk are regions of Iran.

Table 3 The separation performance of the whole seed, epicarp and extract (w/w) of the sumac of different regions

\begin{tabular}{|c|c|c|c|c|c|c|c|}
\hline \multirow{3}{*}{ Region } & \multicolumn{4}{|c|}{ Extraction efficiency (\%) } & \multirow{3}{*}{ Epicarp efficiency (\%) } & \multirow{3}{*}{ Fruit efficiency (\%) } & \multirow{3}{*}{ Reference } \\
\hline & \multicolumn{2}{|l|}{ Seed } & \multicolumn{2}{|l|}{ Epicarp } & & & \\
\hline & Ethanolic & Aqueous & Ethanolic & Aqueous & & & \\
\hline Gonabad* & $3.57 \pm 0.5$ & $3.65 \pm 0.4$ & $55.80 \pm 2.9$ & $63.45 \pm 2.1$ & $59.28 \pm 3.1$ & $92.8 \pm 1.1$ & This study \\
\hline Ferdows* & $3.59 \pm 0.4$ & $3.68 \pm 0.6$ & $56.96 \pm 2.5$ & $65.20 \pm 3.4$ & $56.17 \pm 2.8$ & $94.1 \pm 2.3$ & This study \\
\hline Zoshk* & $3.52 \pm 0.5$ & $3.62 \pm 0.3$ & $52.24 \pm 1.8$ & $62.54 \pm 2.7$ & $54.87 \pm 2.3$ & $91.9 \pm 1.6$ & This study \\
\hline Syrian & - & - & 55.23 & - & - & - & Kossah et al. ${ }^{51}$ \\
\hline Turkey & - & - & $63.8 \pm 4.2$ & - & - & - & Özcan $\mathrm{M}$ et al. ${ }^{25}$ \\
\hline
\end{tabular}

*Gonabad, Ferdows and Zoshk are regions of Iran.

\section{Assessment of the antioxidant activity}

DPPH free radical scavenging assay: Scavenging free radicals is one of the most known mechanisms through which antioxidant compounds could prevent lipids oxidation. In this assay, the scavenging of DPPH is followed by monitoring the decrease in absorbance, which occurs due to the reduction by the antioxidant. ${ }^{59}$ The results of the free radical scavenging activity of the aqueous and ethanolic extracts are illustrated in Figure1. As observed, as the extract concentration increased, the extent of free radicals scavenging increased, too. The ethanolic extract showed a higher anti-radical activity at all concentrations.

Overall, the rise in the total phenolic content causes the ability of different extract in free radical scavenging to increase. At higher concentrations of phenolic compounds, the probability of hydrogen donation to free radicals and subsequently the scavenging ability of the extract increases because of the increase in the number of the hydroxyl groups present in the reaction medium. ${ }^{60}$ Scavenging of various extracts depends greatly on the number and position of hydroxyl groups and the molecular weight of phenolic compounds. The hydroxyl groups are more easily accessible in lower-molecularweight phenolic compounds. In addition, phenolic compounds change into phenoxyl free radicals after donating their hydrogen. The stability of these radicals can influence the antioxidant capacity of phenolic compounds, as the less stable phenoxyl radicals compete with DPPH radicals in donating the hydrogen atoms and thus, the scavenging percentage of DPPH free radicals is reduced. ${ }^{61}$

Reducing power: Extraction of antioxidant compounds from plant materials can be conducted through various techniques with different solvents, due to the difference in the chemical nature of these compounds and their unique distribution in the plant tissue. ${ }^{62}$ Application of organic and aqueous solvents is the most common 
method to extract antioxidant compounds from plant tissues. The extracts with electron-donating activity, can end the radical chain and change the active free radicals into more stable products. ${ }^{63}$

Owing to their reducing power, antioxidant compounds reduce $\mathrm{Fe}$ (III) to Fe (II). This reduction could be determined through measuring the formation of blue color at $700 \mathrm{~nm} .{ }^{64}$ In this method, the soluble yellow color of the sample changes into green or blue, depending on the antioxidant or reducing power of the sample. A higher absorbance value displays a higher iron-reducing power.

$$
\begin{aligned}
& \mathrm{K}_{3} \mathrm{Fe}(\mathrm{CN})_{6}+\text { Reductiveagent }=\mathrm{Fe}(\mathrm{CN})_{6}^{-4} \\
& \mathrm{Fe}(\mathrm{CN})_{6}^{-4}+\mathrm{Fecl}_{3} \rightarrow \mathrm{Fe}_{4}\left[\mathrm{Fe}(\mathrm{CN})_{6}\right]_{3}
\end{aligned}
$$

As observed in Figure 2, the iron-reducing activity increased as the sumac and BHT concentration increased. According the results of the present study, the ethanolic extract had a slightly better inhibitory effect compared with BHT; however, the aqueous one was approximately the same as BHT. Furthermore, the iron-reducing power and the total phenol content of the ethanolic extract were higher than those of the aqueous one. The total phenol content and the ironreducing power are associated with each other. Reduction of Fe (III) is often used as an index for electron donating activity, which is the important mechanism for the evaluation of the antioxidant activity of phenolic compounds. ${ }^{65}$

Figure I The percentage of DPPH free radical scavenging by BHT and the aqueous and ethanolic extracts of Iran sumac.
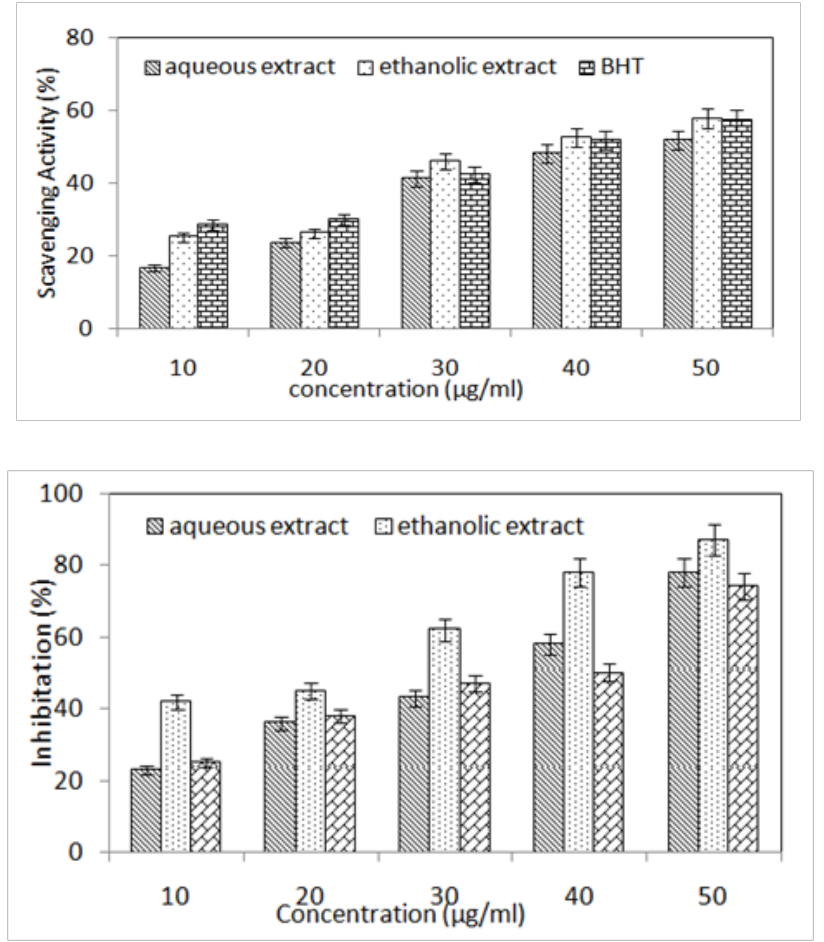

Figure $\mathbf{2}$ The reducing power of $\mathrm{BHT}$ and the aqueous and ethanolic extracts of Iran sumac.

\section{Conclusion}

Some of the physical and chemical properties of the sumac fruits of Iran as well as the antioxidant properties of its aqueous and ethanolic extracts were studied. In this study, some engineering properties of sumac fruit were measured. The average $\mathrm{m}_{1000}$, bulk density and porosity percentage ranged from $15.9-16.9 \mathrm{~g}, 304.6-306.7 \mathrm{~kg} / \mathrm{m}^{3}$ and $68.31-97.26 \%$, respectively. The galvanized sheet with the lowest static friction coefficient was the best surface for the fruit transfer. The mean length, width, thickness and volume were in the range of $4.73-4.98 \mathrm{~mm}, 4.08-4.54 \mathrm{~mm}, 2.33-2.51 \mathrm{~mm}$ and $17.64-22.46 \mathrm{~mm}^{3}$, respectively and the mean sphericity coefficient varied from 0.73 to 0.76. This information is of great importance for the design of the equipment of harvest, transfer and processing of sumac fruit. The present study also exhibited that the antioxidant capacity, free radical scavenging and reducing capacity of the ethanolic extract were higher than those of the aqueous one. Moreover, the ethanolic extract had a larger total phenol and anthocyanin content as compared to the aqueous one.

\section{Acknowledgements}

None.

\section{Conflict of interest}

The author declares no conflict of interest.

\section{References}

1. Beuchat LR, Golden DA. Antimicrobials occurring naturally in foods. Food technology (USA); 1989.

2. Brown CE. Medicinal and Other Uses of North American Plants. A Historical Survey with Special Reference to the Eastern Indian Tribes; 1989.

3. Wetherilt H, Pala M. Herbs and spices indigenous to Turkey. In: Charalambous G editor. Spices, Herbs and Edible Fungi. Developments in Food Science, Amsterdam, Netherlands: Elsevier Science BV; 1999. p. 285-307.

4. Rayne S, Mazza G. Biological activities of extracts from sumac (Rhus spp.): a review. Plant Foods Hum Nutr. 2007;62(4):165-175.

5. Emad M, Gheibi F, Rasouli SM, et al. Medicinal-Industrial plants (Rhus Coriaria). Tehran, Iran: Pooneh publication; 2012.

6. Zargari A. Medicinal plants. 5th ed. Iran: Tehran University Press; 1992. $561 \mathrm{p}$.

7. Amin MN, Hossain MA, Roy KC. Effects of moisture content on some physical properties of lentil seeds. Journal of Food Engineering. 2004;65(1):83-87.

8. Al-Akhawayinial, Bukhari R. Hidayat al-Muta'allimin fi al-Tib. 2nd ed. Iran: Ferdowsi University of Mashhad; 1992.

9. Rhazes Al- Hawi. 1st ed. Academy of Medical Sciences of Islamic Republic of Iran; 2005. 21 p.

10. Avicenna. Al-Ghanoon fi al- Tib (Canon of Medicine). 1sted. Iran: Soroush Press; 1983. 249 p.

11. Heravi A. Al- Abniyahan, Haghayigh al-Adviyah. 1st ed. Iran: Tehran University Press; 1992. 192 p.

12. Al-Bataina BA, Maslat AO, Al-Kofahi MM. Element analysis and 
biological studies on ten oriental spices using XRF and Ames test. $J$ Trace Elem Med Biol. 2003;17(2):85-90.

13. Ozcan M. Antioxidant activities of rosemary, sage, and sumac extracts and their combinations on stability of natural peanut oil. J Med Food. $2003 ; 6(3): 267-270$.

14. Ozcan M. Effect of stomach (Rhus coriaria L.) extracts on the oxidative stability of peanut oil. J Med Food. 2003;6(1):63-66.

15. Ozcan M. Mineral contents of some plants used as condiments in Turkey. Food chem. 2004;84(3):437-440.

16. Bozkurt H. Investigation of the effect of sumac extract and BHT addition on the quality of sucuk (Turkish dry-fermented sausage). J Sci Food Agricul. 2006;86(5):849-856.

17. Giancarlo S, Rosa LM, Nadjafi F, et al. Hypoglycaemic activity of two spices extracts: Rhus coriaria L. and Bunium persicum Boiss. Nat Prod Res. 2006;20(9):882-886.

18. Fazeli MR, Amin Gh, Ahmadian-Attari MM, et al. Antimicrobial effects of five Iranian popular plants on some intestinal bacteria. J Pharm Res 2004;3(Supplement 2):67.

19. Fazeli MR, Ashtiani H, Ahmadian-Attari MM, et al. Antimicrobial effect of Rhus coriaria L. (Sumac) total extract on skin isolates Staphylococcus epidermidis and Corynebacterium xerosis. J Med Plants. 2006;5:27-31.

20. Fazeli MR, Amin Gh, Ahmadian-Attari MM, et al. Antimicrobial activities of Iranian sumac and avishan-e shirazi (Zataria multiflora) against some food-borne bacteria. Food Contr. 2007;18(6):646-649.

21. Ahmadian-Attari MM, Fazeli MR, Ashtiani H, et al. Ant pseudomonas activity of Rhus coriaria L. epicarp extract. Proceeding in the $1^{\text {st }}$ Alborzi Congress of Clinical Microbiology. Shiraz, Iran: Shiraz University of Medical Sciences; 2007.

22. Nsar-Abbas SM, Kadir Halkman A. Antimicrobial effect of water extract of sumac (Rhus coriaria L.) on the growth of some food born bacteria including pathogens. Int J Food Microb. 2004;97(1):63-69.

23. Zalacain A, Prodanov M, Carmona M, et al. Optimisation of extraction and identification of gallotannins from sumac leaves. Biosyst Eng. 2003;84(2):211-216.

24. Candan F. Effect of Rhus coriaria L. (Anacardiaceae) on superoxide radical scavenging and xanthine oxidase activity. $J$ Enzym Inhibit Med Chem. 2003;18(1):59-62.

25. Özcan M, Haciseferogullari H. A condiment [sumac (Rhus coriaria L.) fruits]: some physicochemical properties. Bulgarian Journal of Plant Physiology. 2004;30(3-4):74-84.

26. Kchaou W, Abbes F, Blecker C, et al. Effects of extraction solvents on phenolic contents and antioxidant activities of Tunisian date varieties (Phoenix dactylifera L.). Industrial Crops and Products. 2013;45:262-269.

27. Altuntas E, Ozgoz E, Taser F. Some physical properties of fenugreek (Trigonella foenumgraceum L.) seeds. Journal of Food Engineering. 2005;71:37-43.

28. Amin Gh. Popular medicinal plants of Iran. 1st ed. Vice-chancellorship of Research. Iran: Tehran University of medical sciences; 2005. 178 p.

29. Aviara NA, Gwandzang MI, Haque MA. Physical properties of Guna seeds Journal of Agriculture and Engineering Research. 1999;73(2):105-111.

30. Baryeh EA. Physical properties of millet. Journal of Food Engineering. 2002;51(1):39-46

31. Coskuner Y, Karababa E. Some physical properties of flaxseed. Journal of Food Engineering. 2007;78(3):1067-1073.
32. Coskuner Y, Karababa E. Physical properties of coriander seeds (Coriandrum sativum L.). Journal of Food Engineering. 2007;80(2):408416.

33. Kingsly ARP, Singh DB, Manikantan MR, et al. Moisture dependent physical properties of dried pomegranate seeds. Journal of Food Engineering. 2006;75(4):492-496.

34. Razavi SMA, Mohammadi Moghaddam T, Mohammad Amini A. Physical-Mechanical Properties and Chemical Composition of Balangu (Lallemantiaroyleana (Benth. in Walla.)) Seed. International Journal of Food Engineering. 2008;4(5):1-12.

35. Razavi SMA, Bostan A, Rahbari R. Computer image analysis and other physico mechanical properties of wild sage seed (Salvia macrosiphon). International Journal of Food Properties. 2010;13(2):308-316.

36. Razavi SMA, Bostan A, Rezaie M. Image processing and physicmechanical properties of basil seed (Ocimum basilicum). Journal of Food Process Engineering. 2010;33(1):51-64.

37. Sacilik K, Ozturk R, Keskin R. Some physical properties of hemp seed. Bio systems engineering. 2003;86(2):191-198.

38. Tabata baeefar A. Moisture-dependent physical properties of wheat. International Agrophysics. 2003;17:207-211.

39. Tunde-Akintunde TY, Akintunde BO. Some physical properties of sesame seed. Biosystems Engineering. 2004;88(1):59-65.

40. Vilche C, Gely M, Santalla E. Physical Properties of Quinoa Seeds. Biosystems Engineering. 2003;86(1):59-65.

41. Oke MO, Awonorin SO, Sanni LO, et al. Determination of Some Selected Engineering Properties of Sweet Potato Cuts as Function of Temperature. Journal of Food Technology. 2007;5(1):66-70.

42. Sirisomboon P, Kitchaiya P, Pholpho T, et al. Physical and mechanical properties of Jatropha curcas L. Fruits, nuts and Kernels. Biosystems Engineering. 2007;97(2):201-207.

43. Özgüven F, Vursavuş K. Some physical, mechanical and aerodynamic properties of pine (Pinus pinea) nuts. Journal of Food Engineering. 2005;68(2):191-196

44. Pearson RG. The or. Chim. Acta, 1970, 16, 107. Acc Chem Res. 1971;4:152.

45. Gramza A, khokhar S, Yoko S, et al. Antioxidant activity of tea extracts in lipids and correlation with polyphenol content. European Journal of Lipid Science and Technology. 2006;108(4):351-362.

46. Marutti LRB, Barreto GPM, Bragagnolo N, et al. Free Radical Scavenging Activity of Ethanolic Extracts from Herbs and Spices Commercialized in Brazil. Brazilian Archives of Biology and Technology. 2008;51(6):12251232.

47. Arabshahi S, Urooj A. Antioxidant properties of various solvent extracts of mulberry (Morus indica L.) leaves. Food Chemistry. 2007;102:1233-1240.

48. Prior RL, Cao G, Martin A, et al. Antioxidant capacity as influenced by total phenolic and anthocyanin content, maturity, and variety of Vaccinium species. Journal of Agricultural and Food Chemistry. 1998;46(7):26862693.

49. Hatano T, Kagawa H, Yasahara HT, et al. The effect of extracts on DPPH radical was estimated according to the method. Food Chem 1988;78(3):347-354

50. Razavi SMA, Akbari R. Biophysics Properties of Agricultural Products and Foodstuffs. Mashhad, Iran: Publication of Ferdowsi University; 2005.

51. Kossah R, Nsabimana C, Zhao J, et al. Comparative study on the chemical composition of Syrian sumac (Rhus coriaria L.) and Chinese sumac (Rhus typhina L.) fruits. Pakistan Journal of Nutrition. 2009;8(10):1570-1574. 
52. Tsao R, Deng Z. Separation procedures for naturally occurring antioxidant phytochemicals. J Chromatogr B Analyt Technol Biomed Life Sci. 2004;812(1-2):85-99.

53. Chirinos R, Rogez H, Campos D, et al. Optimization of extraction conditions of antioxidant phenolic compounds from mashua (Tropaeolum tuberosum Ruíz \& Pavón) tubers. Separation and Purification Technology. 2007;55(2):217-225.

54. Faller ALK, Fialho E. The antioxidant capacity and polyphenol content of organic and conventional retail vegetables after domestic cooking. Food Research International. 2009;42(1):210-215.

55. Mata AT, Proença C, Ferreira AR, et al. Antioxidant and antiacetylcholinesterase activities of five plants used as Portuguese food spices. Food chemistry. 2007;103(3):778-786.

56. Anwar F, Kalsoom U, Sultana B, et al. Effect of drying method and extraction solvent on the total phenolics and antioxidant activity of cauliflower (Brassica oleracea L.) extracts. International Food Research Journal. 2013;20(2):653-659.

57. Guvenc A, Koyuncu M. A study on the main active compounds of leaves and fruits of Rhuscoriaria L. Turk. J Med Sci. 1994;20:11-13.

58. Mavlyanov SM, Islambekov Sh Yu, Karimdzhanov AK, et al. Anthocyans and organic acids of the fruits of some species of sumac. Chem Nat Comp. 1997;33:209.
59. Ferreres F, Sousa C, Valentão P, et al. Tronchuda cabbage (Brassica oleracea L. var. costata DC) seeds: Phytochemical characterization and antioxidant potential. Food Chemistry. 2007;101(2):549-558.

60. Sánchez-Moreno C, Larrauri JA, Saura-Calixto F. Free radical scavenging capacity and inhibition of lipid oxidation of wines, grape juices and related polyphenolic constituents. Food Research International. 1999;32(6):407412.

61. Jung CH, Seog HM, Choi IW, et al. Antioxidant properties of various solvent extracts from wild ginseng leaves. LWT-Food Science and Technology. 2006;39(3):266-274.

62. Anwar F, Przybylski R. Effect of solvents extraction on total phenolics and antioxidant activity of extractions from flaxseed (Linum usitatissimum L.). Acta Sci Pol Technol Aliment. 2012;11(3):293-301.

63. Pan M, Jiang T, Pan J. Antioxidant activities of rapeseed protein hydrolysates. Food Bioprocess Technology. 2011;4(7):1144-1152.

64. Chung YC, Chang CT, Chao WW, et al. Antioxidative activity and safety of the 50 ethanolic extract from red bean fermented by Bacillus subtilis IMR-NK1. J Agric Food Chem. 2002;50(8):2454-2458.

65. Dorman HJD, Peltoketo A, Hiltunen R, et al. Characterisation of the antioxidant properties of de-odourised aqueous extracts from selected Lamiaceae herbs. Food chemistry. 2003;83(2):255-262. 